\title{
FAKTOR-FAKTOR YANG MEMPENGARUHI MINAT MENGGUNAKAN FINTECH SYARIAH
}

\author{
Mira Misissaifi*, Jaka Sriyana \\ Universitas Islam Indonesia (UII) Yogyakarta, Indonesia \\ mirachan1024@gmail.com, jakasriyana@uii.ac.id \\ https://doi.org/10.46367/iqtishaduna.v10i1.276
}

Received: Jan 27, 2021 Revised: Jun 20, 2021 Accepted: Jun 22, 2021 Published: Jun 29, 2021

\begin{abstract}
This study aims to identify the factors that influence the interest of the people of Yogyakarta in using Islamic fintech by using the technology acceptance model (TAM). The sampling technique used purposive sampling so that the number of samples obtained was 150 respondents. This study was analyzed using a structural equation model partial least square (SEM-PLS) with the help of SmartPLS 3.2.9 software. The results of this study indicate that the intention to use sharia fintech is influenced by the individual attitude factor towards the presence of sharia fintech. Attitudes to use sharia fintech are influenced by perceived usefulness factors, perceived ease of use, and sharia compliance inherent in sharia fintech. This research can be considered for sharia fintech start-up companies in improving and optimizing the use of sharia fintech.
\end{abstract}

Keywords: Sharia Fintech, Interest, TAM, SEM, Sharia Compliance.

\begin{abstract}
ABSTRAK
Penelitian ini bertujuan untuk mengidentifikasi faktor-faktor yang mempengaruhi minat masyarakat Yogyakarta dalam menggunakan fintech syariah dengan menggunakan technology acceptance model (TAM). Teknik pengambilan sampel menggunakan purposive sampling, sehingga didapat jumlah sampel sebanyak 150 responden. Penelitian ini dianalisis menggunakan structural equation model partial least square (SEM-PLS) dengan bantuan software SmartPLS 3.2.9. Hasil dari penelitian ini menunjukkan bahwa niat menggunakan fintech syariah dipengaruhi oleh faktor sikap individu terhadap hadirnya fintech syariah. Sikap untuk menggunakan fintech syariah dipengaruhi oleh faktor persepsi kegunaan yang dirasakan, persepsi kemudahan menggunakan dan adanya sharia compliance yang melekat pada fintech syariah. Penelitian ini dapat menjadi bahan pertimbangan bagi perusahaan start up fintech syariah dalam meningkatkan dan mengoptimalkan penggunaan fintech syariah.
\end{abstract}

Kata Kunci: Fintech Syariah, Minat, TAM, SEM, Sharia Compliance.

\section{PENDAHULUAN}

Beberapa tahun terakhir perkembangan fintech semakin meningkat, baik yang beroperasi secara konvensional maupun menggunakan prinsip syariah. 
Berdasarkan data per 26 Desember 2019 di Indonesia ada sekitar 164 perusahaan fintech lending yang terdaftar di OJK (OJK 2019). 139 di antaranya masih dalam status terdaftar sedangkan 25 perusahaan fintech sudah mengantongi izin dari OJK. Dilihat dari prinsip operasionalnya, sekitar 152 fintech yang melakukan operasionalnya secara konvensional dan sekitar 12 fintech yang beroperasi dengan prinsip syariah. Pada tahun 2014 salah satu fintech yang berasal dari Singapura yakni Ethis Crowd berhasil menguasai pasar Indonesia dan kini sudah mempunyai layanan syariah. Keadaan ini secara tidak langsung turut mendorong pertumbuhan fintech syariah di Indonesia untuk terus berkembang. Sehingga pada tahun 2017 Paytren menjadi fintech syariah pertama yang mendapatkan sertifikasi halal MUI di Indonesia. Namun harus diakui bahwa perkembangan jumlah fintech syariah di indonesia saat ini masih jauh jika dibandingkan dengan fintech konvensional (Nasution 2017). Hal yang membedakan antara fintech syariah dan fintech konvensional adalah prinsip-prinsip yang digunakan serta adanya dewan pengawas yang bertugas mengawasi setiap kegiatannya. Kehadiran fintech syariah menjadi jawaban akan kebutuhan masyarakat Indonesia yang mayoritasnya beragama Islam agar terhindar dari praktik riba, gharar, dan maysir.

Salah satu teori yang seringkali digunakan untuk melihat penerimaan atas hadirnya sebuah teknologi yang baru dikenal dengan technology acceptance model (TAM). TAM merupakan kerangka model yang ditemukan oleh Davis (1989) dengan mengembangkan kerangka pemikiran terkait niat memanfaatkan sebuah teknologi informasi. TAM merupakan satu diantara banyak model penelitian yang berpengaruh dalam studi determinan penerimaan sebuah teknologi informasi. Terdapat banyak penelitian yang menggunakan TAM sebagai model dasar lalu dimodifikasi dengan beberapa variabel yang lain dengan hasil yang tentunya berbeda-beda. Seperti halnya Chuang, Liu, and Kao (2016) yang melakukan penelitian dengan menggunakan model TAM yang dimodifikasi dengan beberapa variabel lainnya seperti kepercayaan merek dan layanan untuk memahami pengaruh pada niat menggunakan. Penelitian ini menyatakan bahwa variabel kepercayaan merek dan layanan, dan persepsi kemudahan menggunakan memiliki pengaruh positif dan signifikan terhadap sikap dalam penggunaan layanan fintech. Hal ini menunjukkan bahwa teknologi semakin digunakan dapat menumbuhkan kepercayaan dan mampu memberikan kemudahan. Temuan dari Chuang, Liu, and Kao (2016) berbeda dengan temuan yang dilakukan oleh Priyono (2017) yang menunjukkan bahwa variabel kepercayaan berpengaruh negative terhadap minat menggunakan fintech jenis Go-Pay. Keadaan ini tentu saja menandakan bahwa semakin rendah kepercayaan pengguna terhadap teknologi fintech maka akan semakin rendah minat untuk menggunakannya. Amalia (2018) dengan menggunakan pendekatan TAM dan theory of planned behavior (TPB) melakukan penelitian terkait fintech syariah yang dalam hal ini adalah Paytren sebagai salah satu alat pembayaran. Hasil dari kajian tersebut menunjukkan bahwa variabel persepsi manfaat, sikap, persepsi kemudahan penggunaan dan norma subjektif memiliki pengaruh terhadap minat untuk menggunakan aplikasi Paytren sebagai alat transaksi pembayaran.

Mengingat faktor-faktor yang digunakan pada penelitian sebelumnya belum sepenuhnya menjadi alasan kuat untuk menarik minat masyarakat dalam menggunakan sebuah teknologi, maka diperlukan fakktor-faktor lain yang diharapkan bisa menjelaskan minat masyarakat dalam menggunakan sebuah 
teknologi baru khsususnya fintech syariah. Penelitian ini mencoba menggabungkan beberapa variabel tambahan seperti norma subjektif, kepercayaan, risiko dan sharia compliance sehingga dapat menjadi gap penelitian. Sharia compliance dianggap sebagai faktor yang penting mengingat objek penelitian merupakan layanan yang berbasis syariah serta belum ditemukan penelitian yang menggunakan variabel ini untuk melihat penerimaan fintech syariah.

Tujuan dari penelitian ini adalah untuk mengetahui faktor-faktor yang mempengaruhi minat masyarakat terhadap teknologi baru dalam keuangan yaitu fintech. Selain itu penelitian ini juga dapat menambah pengetahuan dan wawasan terbaru terhadap teori-teori di dalam bidang keuangan. Oleh karena itu penelitian ini diharapkan dapat memberikan informasi dan referensi kepada masyarakat yang sudah ataupun akan menggunakan fintech syariah sebagai alat transaksi keuangannya.

\section{TELAAH LITERATUR}

\section{Fintech Syariah}

Fintech merupakan industri baru yang terdiri atas perusahaan-perusahaan yang menggunakan teknologi sebagai sistem keuangan dan penyampaian layanan keuangan yang lebih efisien (World Bank Group 2016; Nizar 2017). Sebagai alat inovasi yang baru, fintech merujuk kepada penggunaan software atau perangkat lunak dan platform digital yang bertujuan memberikan pelayanan keuangan kepada pengguna dalam berbagai bentuk. Fintech tidak terbatas pada sektor tertentu seperti pembiayaan pada model bisnis (Peer to Peer) P2P lending, tetapi juga meliputi kepada seluruh bentuk pelayanan dan produk yang secara tradisional disediakan oleh industri jasa keuangan (Arner, Barberist, Buckley 2015). Sama halnya dengan pengertian fintech secara umum, fintech syariah merupakan layanan keuangan secara teknologi yang mengutamakan prinsip-prinsip syariah sebagai dasar dalam operasionalnya.

\section{Teori Technology Acceptance Model (TAM)}

Technology Acceptance Model atau diringkas dengan TAM merupakan model yang diusulkan oleh Davis, Bagozzi, and Warshaw (1989) membahas tentang teori penerimaan suatu teknologi yang baru. Model ini merupakan pengembangan dari theory reasoned action (TRA) yang digagas oleh (Ajzen and Fishbein 1977). Model ini memberikan suatu pemahaman yang lebih luas terkait penerimaan sebuah teknologi oleh penggunanya. Tujuan dari model TAM ini yaitu untuk menjelaskan faktor-faktor yang menjadi penentu penerimaan suatu teknologi berbasis informasi secara umum dan menjelaskan perilaku pengguna akhir (end-user) dari teknologi informasi tersebut dengan variasi yang cukup luas dari populasi pengguna. Kunci dari model TAM adalah menyediakan basis untuk mengetahui pengaruh dari faktor eksternal terhadap kepercayaan internal yaitu sikap dan niat (Siregar 2011).

\section{Norma Subjektif (Subjective Norm)}

Fishbein and Ajzen (1975) mendefinisikan norma subjektif (NS) sebagai persepsi seorang individu terkait dorongan dari orang-orang yang memiliki peran 
penting terhadap dirinya untuk melakukan atau tidak melakukan sesuatu. Secara singkat bisa dipahami bahwa NS merupakan keyakinan pengguna terhadap keputusan yang akan dilakukan dengan pertimbangan orang-orang terdekat, sehingga norma subjektif berarti sebuah sikap untuk memperhitungkan pengaruh sosial atas perilaku dirinya. Amalia (2018); Niswah, Mutmainah, and Legowati (2019) di dalam penelitiannya menunjukkan bahwa NS memiliki pengaruh terhadap persepsi kegunaan sebuah teknologi yang baru. Hal ini menandakan bahwa semakin tinggi dorongan orang-orang dalam menggunakan sebuah teknologi maka akan berpengaruh terhadap semakin kuatnya persepsi dirinya akan kegunaan dari teknologi tersebut.

\section{Persepsi Kegunaan (Perceived usefullnes)}

Menurut Davis (1989) persepsi kegunaan (PKG) adalah ukuran kepercayaan dari pengguna terhadap penggunaan sebuah sistem yang akan memberikan manfaat berupa meningkatkan kinerjanya. Seseorang akan cenderung menggunakan sebuah sistem teknologi informasi ketika mempunyai keyakinan bahwa aktivitas atau pekerjaannya akan lebih mudah dan akan mampu lebih meningkat ketika menggunakan teknologi tersebut. Hal ini menggambarkan bahwa suatu teknologi diterima dan dipercaya karena memiliki manfaat atau kegunaan bagi penggunanya. Oleh karena itu Davis (1989) memasukkan PKG ke dalam bagian dari TAM. Lebih lanjut Davis (1989) mendefinisikan PKG sebagai kondisi pengguna yang merasakan manfaat atas sistem teknlogi informasi yang digunakan baik untuk meningkatkan kinerjanya atau mempermudah aktivitas pekerjaannya. Sebaliknya jika sistem teknologi informasi tersebut kurang memberikan manfaat maka pengguna tentu tidak akan menggunakannya. Seperti penelitian yang dilakukan oleh Nurul and Ningrat (2018) bahwa keputusan untuk menggunakan produk investasi fintech yang berbasis syariah dipengaruh karena adanya kegunaan atau manfaat yang melekat pada teknologi tersebut. Sama halnya juga dengan yang dilakukan oleh Amalia (2018); Sari, Safitri, and Anggraini (2019); Priyono (2017); Siri, Fitriyani, and Herliana (2017) bahwa PKG akan berpengaruh terhadap niat untuk menggunakan teknologi yang baru.

\section{Persepi Kemudahan Menggunakan (Perceive Easy of Use)}

Persepsi kemudahan menggunakan (PKM) diartikan sebagai suatu keadaan atau kondisi seseorang yang percaya dan yakin bahwa dengan menggunakan sebuah sistem atau teknologi tidak harus dibantu oleh orang lain serta tidak membutuhkan usaha yang besar Davis (1989). Hal ini menandakan bahwa dengan menggunakan teknologi tersebut akan membebaskan pengguna dari masalah dan kerumitan. Dengan kata lain PKM merupakan ukuran sejauh mana seseorang percaya bahwa dengan menggunakan teknologi tertentu dia tidak membutuhkan usaha atau bantuan orang lain. Sehingga ketika sebuah teknologi baru dirasakan oleh pengguna mudah untuk digunakan, dan tidak membutuhkan tenaga dan waktu yang banyak, maka teknologi baru tersebut lebih mungkin diterima oleh pengguna (Chuang, Liu, and Kao 2016). Oleh karena itu PKM juga termasuk ke dalam model TAM yang diusulkan oleh Davis (1989); Amalia (2018) dalam kajiannya juga menunjukkan bahwa dengan adanya PKM turut mendorong pengguna untuk menggunakan Paytren sebagai salah satu teknologi terbaru dalam melakukan pembayaran, sedangkan Sari, Safitri, and Anggraini (2019) 
menemukan bahwa kemudahan yang ditawarkan juga akan mendorong para milenial dalam memilih mobile banking sebagai salah satu teknologi keuangannya. Hal yang sama dilakukan oleh pengguna dompet digital yaitu GoPay (Priyono 2017).

\section{Kepercayaan (Trust)}

Di dalam suatu transaksi ekonomi, kepercayaan (KPC) menjadi aspek yang paling penting untuk mengidentifikasi perilaku seseorang. KPC menjadi hal yang penting karena akan mempengaruhi perilaku pengguna dan terbukti sangat penting ketika hal tersebut dikaitkan dengan lingkungan yang tidak pasti seperti halnya penggunaan fintech syariah. Menurut Pavlou (2014) KPC merupakan penilaian atas hubungan antara seseorang dengan orang lain yang melakukan transaksi tertentu, penilaian ini berdasarkan kesesuaian antara harapan dengan sebuah lingkungan yang dipenuhi dengan ketidakpastian. Bahkan dalam hal apapun, setiap interaksi membutuhkan elemen KPC, terutama yang dilakukan di lingkungan teknologi informasi yang tidak pasti. KPC juga akan membawa kepada tingkat kepuasan dari pengguna. Pengguna yang merasa puas akan layanan yang diberikan oleh pihak penyedia sistem teknologi akan menaruh tingkat KPC yang tinggi (Chuang, Liu, and Kao 2016).

\section{Risiko (Risk)}

Risiko (RSK) merupakan suatu keadaan yang sangat dihindari dalam melakukan aktivitas apapun, termasuk dalam penggunaan fintech. Hal ini wajar karena selain manfaat yang dirasakan sebuah inovasi tidak lepas dari adanya risiko. Di saat membuat keputusan tanpa mengacu informasi yang jelas akan berakibat kepada tingkat risiko atau ketidakpastian dalam menggunakan sebuah teknologi (Kim, Ferrin, and Rao 2008).

\section{Kepatuhan Syariah (Sharia Compliance)}

Sharia Compliance (SHC) merupakan bagian penting bagi industri keuangan syariah dalam segi pengelolaan maupun operasionalnya. Oleh karena itu harus ada dewan pengawas syariah (DPS) bagi setiap institusi keuangan yang berbasis syariah untuk mendukung setiap aktivitasnya. Salah satu dari tugas dewan pengawas syariah adalah untuk mengawasi penerapan kontrak maupun akad yang dipraktikkan di lembaga tersebut (Janusi 2012). Jika melihat sejarah perkembangan lembaga keuangan syariah, pemenuhan akan prinsip-prinsip syariah menjadi penting karena alasan dari lahirnya prinsip ini disebabkan munculnya kesadaran masyarakat muslim yang ingin menjalankan seluruh aktivitas keuangannya berdasarkan Al-Quran dan Sunnah. Oleh karena itulah, jaminan mengenai pemenuhan terhadap syariah $(S H C)$ dari seluruh aktivitas fintech syariah merupakan hal yang sangat penting juga dalam kegiatan usaha fintech syariah.

\section{Sikap (Attitude)}

Sikap (SKP) merupakan wujud dari perasaan baik itu positif atau negatif yang dihasilkan ketika seseorang menggunakan sebuah teknologi baru. Ketika seseorang baik itu pengguna atau tidak memiliki sikap positif yang lebih tinggi terhadap kehadiran sebuah teknologi baru, maka niat untuk mengadopsi atau 
menggunakan teknologi tersebut akan relatif lebih tinggi (Chuang, Liu, and Kao 2016). Dengan kata lain SKP merupakan cerminan dari perasaan suka atau tidak suka seorang individu melalui tingkah lakunya. Hal ini berarti bahwa SKP akan berkembang seiring waktu ketika individu tersebut mendapatkan pengalaman dari penggunaan teknologi yang digunakan. Aslam, Ham, and Arif (2017) di dalam penelitiannya terkait penggunaan mobile payment menunjukkan bahwa SKP memiliki pengaruh terhadap keputusan dalam menggunakan mobile payment. Chuang, Liu, and Kao (2016); Amalia (2018) juga menyatakan hal yang sama bahwa SKP memiliki pengaruh terhadap niat seseorang dalam menggunakan sebuah teknologi yang baru.

\section{Niat Menggunakan (Intention Behaviour)}

Menurut Chuang, Liu, and Kao (2016) Niat menggunakan (NMG) merupakan dimensi yang berkaitan dengan kecenderungan perilaku individu untuk menggunakan suatu layanan teknologi informasi. Tingkat keinginan untuk menggunakan sebuah teknologi informasi pada seseorang dapat dilihat dari perilaku atau sikap individu tersebut terhadap teknologi yang dimaksud, misalnya keinginan untuk tetap menggunakannya dan keinginan untuk memotivasi pengguna lain. Ketika sebuah layanan yang diberikan oleh teknologi informasi dianggap dapat menguntungkan dirinya, maka individu tersebut akan cenderung tetap menggunakan layanan teknologi informasi tersebut bahkan akan mengajak orang lain untuk ikut menggunakannya.

Penelitian-penelitian sebelumnya memberikan gambaran bahwa tingkat adopsi teknologi dapat mempengaruhi secara positif terhadap sikap dan keinginan untuk memakai layanan fintech dan service teknologi. Sehingga berdasarkan hasil penelitian-penelitian tersebut maka dapat diturunkan beberapa hipotesis sebagai berikut:

H1: Norma subjektif (NS) berpengaruh positif dan signifikan terhadap niat menggunakan (NMG) fintech syariah.

H2: Norma subjektif (NS) berpengaruh positif dan signifikan terhadap persepsi kegunaan (PKG) fintech syariah.

H3: Persepsi kegunaan (PKG) berpengaruh positif dan signifikan terhadap sikap (SKP) menggunakan fintech syariah.

H4: Kemudahan menggunakan (PKM) berpengaruh positif dan signifikan terhadap persepsi kegunaan (PKG).

H5: Persepsi kemudahan menggunakan (PKM) berpengaruh positif dan signifikan terhadap kepercayaan (KPC).

H6: Persepsi kemudahan menggunakan (PKM) berpengaruh positif dan signifikan sikap (SKP) untuk Menggunakan Fintech Syariah

H7: Kepercayaan (KPC) berpengaruh positif dan signifikan terhadap risiko (RSK) menggunakan fintech syariah.

H8: Risiko (RSK) berpengaruh negatif dan signifikan terhadap sikap (SKP) untuk menggunakan fintech syariah.

H9: Sharia compliance (SHC) berpengaruh positif dan signifikan terhadap sikap (SKP) menggunakan fintech syariah.

H10: Sikap (SKP) berpengaruh positif dan signifikan terhadap niat menggunakan (NMG) fintech syariah. 


\section{METODE PENELITIAN}

Penelitian ini merupakan penelitian kuantitatif, yang dilaksanakan di Yogyakarta pada tahun 2020 dengan populasi yaitu masyarakat yang berdomisili di Yogyakarta. Teknik pengambilan sampel menggunakan purposive sampling, dengan tujuan agar dapat memperhatikan proporsi kategori dalam populasi pada penelitian ini. Pengambilan sampel berdasarkan pada masyarakat yang menggunakan fintech, sehingga sampel diperoleh sebanyak 150 responden. Metode pengumpulan data yang digunakan adalah kuesioner dan kepustakaan. Data yang dikumpulkan kemudian dianalisis menggunakan analisis structure equation model partial least square (SEM-PLS) dengan menggunakan alat bantu berupa software SmartPLS Versi 3.2.9.

\section{HASIL DAN PEMBAHASAN PENELITIAN}

\section{Uji Validitas Data}

Suatu indikator mampu dianggap valid ketika memiliki nilai AVE besar dari 0,5 atau memperlihatkan seluruh outer loading dimensi variabel memiliki nilai loading > 0,5 sehingga dapat dikatakan bahwa pengukuran tersebut memenuhi kriteria validitas konvergen (Chin 1998). Uji validitas diskriminan dapat jika nilai akar kuadrat AVE lebih besar daripada nilai korelasi antar konstruk (Ghozali 2006). Sedangkan cara lain untuk memenuhi uji validitas diskriminan adalah dengan melihat nilai cross loading untuk setiap instrument harus lebih dari 0,5 (Fornell and Larcker 1981). Berdasarkan hasil uji validitas pada estimasi model (Gambar 1), variabel NS memiliki nilai loading terendah 0,770 dan tertinggi 0,862. Variabel PKG memiliki nilai loading terendah 0,773 dan tertinggi 0,876 . Variabel PKM memiliki nilai loading terendah 0,812 dan tertinggi 0,922 . Variabel KPC memiliki nilai loading terendah 0,768 dan tertinggi 0,958 . Variabel RSK memiliki nilai loading terendah 0,764 dan tertinggi 0,939. Variabel SHC memiliki nilai loading terendah 0,866 dan tertinggi 0,951. Variabel SKP memiliki nilai loading terendah 0,793 dan tertinggi 0,934. Variabel NMG memiliki nilai loading terendah 0,914 dan tertinggi 0,922 . Hasil uji validitas dari semua item variabel yang ada, nilai loadingnya lebih besar dari 0,5 maka data penelitian ini bisa dikatakan valid.

\section{Uji Reliabilitas}

Untuk menguji reabilitas suatu konstruk variabel, dapat dilihat melalui nilai composite reliability. Suatu konstruk akan dinyatakan reliable ketika memiliki composite reliability besar dari 0,7 (Chin 1998). Berdasarkan Tabel 1 dapat dilihat bahwa semua variabel memiliki nilai composite reliability lebih besar dari 0,7, sehingga data penelitian ini dapat dikatakan reliable.

\section{Uji Hipotesis}

Pengujian hipotesis merupakan bentuk evaluasi inner model pada uji statistik pada penelitian ini. Pengujian hipotesis dengan menggunakan metode SEM-PLS dengan menggunakan alat uji SmartPLS Versi 3.2.9 yang diketahui nilai dari masing-masing variabel dalam penelitian ini. Variabel yang diuji meliputi variabel norma subjektif (NS), persepsi kegunaan (PKG), persepsi 
kemudahan menggunakan (PKM), kepercayaan (KPC), risiko (RSK), sharia compliance (SHC), sikap (SKP) dan niat menggunakan (NMG). Hasil ringkasan estimasi model untuk path coefficients pada Gambar 1 disajikan pada Tabel 2. Hasil uji hipotesis disajikan pada Tabel 2, dimana p value merupakan salah satu nilai penentu hasil hipotesis, jika $\mathrm{p}$ value $<0,05$ maka hipotesis diterima, selain itu hipotesis ditolak.

Tabel 1 Hasil Uji Reliabilitas

\begin{tabular}{lc}
\hline \multicolumn{1}{c}{ Variable } & $\begin{array}{c}\text { Composite } \\
\text { Reliability }\end{array}$ \\
\hline Norma Subjektif (NS) & 0,906 \\
Persepsi Kegunaan (PKG) & 0,910 \\
Persepsi Kemudahan Menggunakan (PKM) & 0,963 \\
Kepercayaan (KPC) & 0,929 \\
Risiko (RSK) & 0,941 \\
Sharia Compliance (SHC) & 0,975 \\
Sikap (SKP) & 0,945 \\
Niat Menggunakan (NMG) & 0,915 \\
\hline Sumber: data olahan &
\end{tabular}

Sumber: data olahan

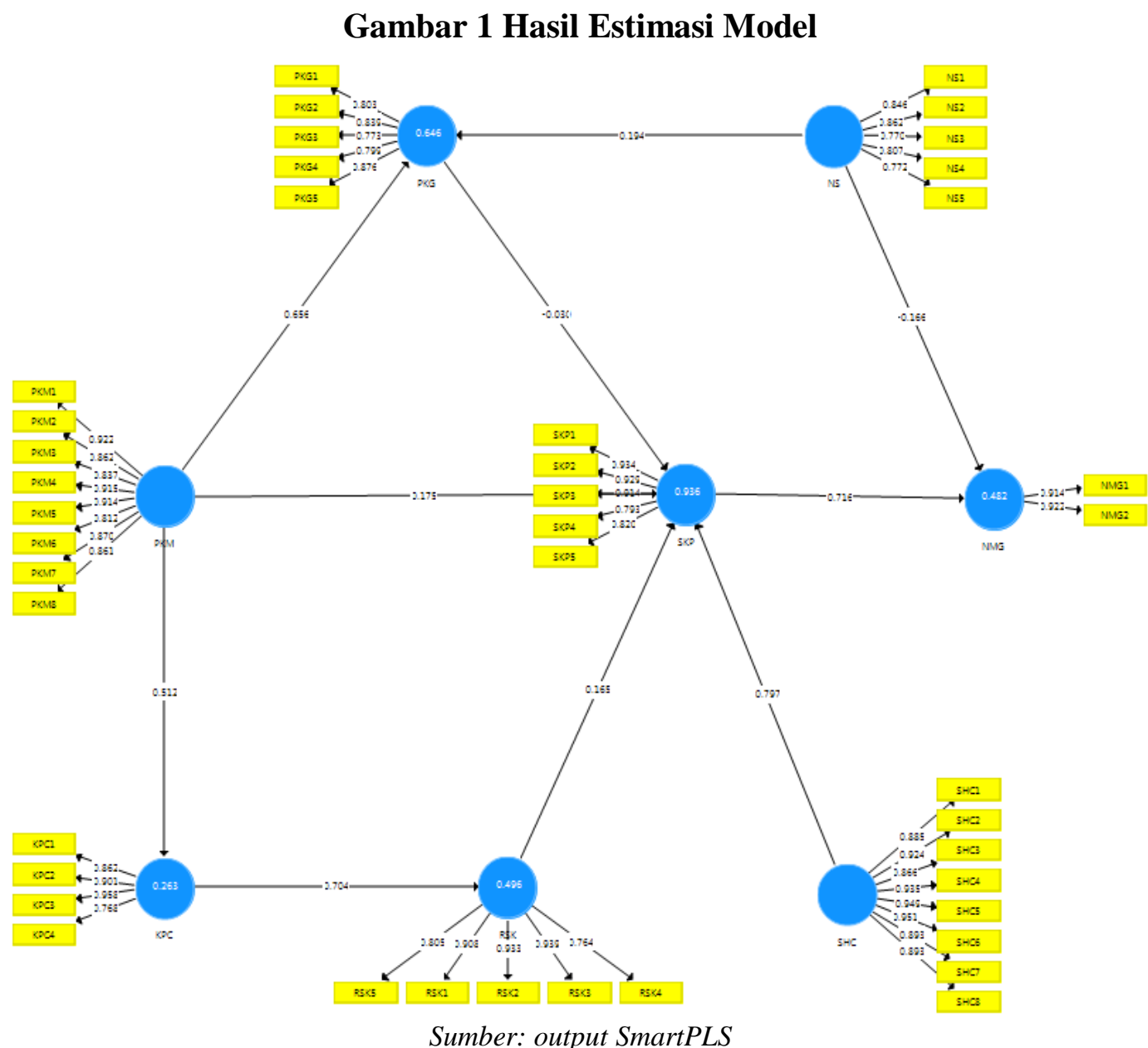


Tabel 2 Hasil Uji Hipotesis

\begin{tabular}{ccccc}
\hline Hipotesis & $\begin{array}{c}\text { Path } \\
\text { Coefficients }\end{array}$ & T Statistics & P Value \\
\hline H1 & NS $\rightarrow$ PKG & 0,194 & 3,243 & 0,002 \\
H2 & NS $\rightarrow$ NMG & $-0,166$ & 2,598 & 0,012 \\
H3 & PKG $\rightarrow$ SKP & $-0,030$ & 0,970 & 0,343 \\
H4 & PKM $\rightarrow$ PKG & 0,656 & 11,770 & 0,000 \\
H5 & PKM $\rightarrow$ KPC & 0,512 & 12,021 & 0,000 \\
H6 & PKM $\rightarrow$ SKP & 0,656 & 11,770 & 0,000 \\
H7 & KPC $\rightarrow$ RSK & 0,704 & 15,686 & 0,000 \\
H8 & RSK $\rightarrow$ SKP & 0,165 & 8,445 & 0,000 \\
H9 & SHC $\rightarrow$ SKP & 0,797 & 32,282 & 0,000 \\
H10 & SKP $\rightarrow$ NMG & 0,716 & 12,017 & 0,000 \\
\hline Sumber: data olahan & & &
\end{tabular}

Berdasarkan Tabel 2, hasil pengujian menunjukan pengaruh variabel NS terhadap PKG memiliki $\mathrm{p}$ value 0,002 , berarti $0,002<0,05$ sehingga $\mathrm{H} 1$ diterima. Pengaruh variabel NS terhadap NMG memiliki p value 0,012 , berarti $0,012<0,05$ sehingga $\mathrm{H} 2$ diterima. Pengaruh variabel PKG terhadap SKP memiliki $\mathrm{p}$ value 0,343 , berarti $0,343<0,05$ sehingga $\mathrm{H} 3$ ditolak. Pengaruh variabel PKM terhadap PKG memiliki $\mathrm{p}$ value 0,000 , berarti $0,000<0,05$ sehingga $\mathrm{H} 4$ diterima. Pengaruh variabel PKM terhadap KPC memiliki p value 0,000 , berarti $0,000<$ 0,05 sehingga $\mathrm{H} 5$ diterima. Pengaruh variabel PKM terhadap SKP memiliki $\mathrm{p}$ value 0,000 , berarti $0,000<0,05$ sehingga H6 diterima. Pengaruh variabel KPC terhadap RSK memiliki p value 0,000, berarti 0,000 < 0,05 sehingga $\mathrm{H} 7$ diterima. Pengaruh variabel RSK terhadap SKP memiliki $\mathrm{p}$ value 0,000 , berarti $0,000<$ 0,05 sehingga $\mathrm{H} 8$ diterima. Pengaruh variabel SHC terhadap SKP memiliki $\mathrm{p}$ value 0,000 , berarti $0,000<0,05$ sehingga $\mathrm{H} 9$ diterima. Pengaruh variabel SKP terhadap NMG memiliki $\mathrm{p}$ value 0,000 , berarti $0,000<0,05$ sehingga H10 diterima.

Setelah model yang diajukan diterima dan telah memenuhi syarat pengujian outer model, maka langkah yang harus dilakukan selanjutnya adalah melakukan pengujian inner model atau uji model struktural. Hasil pengujian inner model bisa dilihat dari nilai $R$-Square, tujuannya adalah untuk menilai seberapa besar pengaruh variabel eksogen (independen) tertentu terhadap variabel endogen (dependen) (Abdillah and Hartono 2015).

Tabel 3 Nilai $R$-Square

\begin{tabular}{lc}
\hline \multicolumn{1}{c}{ Variable } & R Square \\
\hline Persepsi Kegunaan (PKG) & 0,646 \\
Kepercayaan (KPC) & 0,263 \\
Risiko (RSK) & 0,496 \\
Sikap (SKP) & 0,936 \\
Niat Menggunakan (NMG) & 0,482 \\
\hline Sumber: data olahan &
\end{tabular}

Pada Tabel 3 dapat dilihat bahwa variabel PKG memiliki nilai $R$-Square sebesar 0,646, nilai tersebut menunjukkan variabel NS dan PKM mempengaruhi variabel PKG sebesar 64,6\%, dan sisanya sebesar 35,4\% dipengaruhi oleh 
variabel lainnya. Variabel KPC memiliki nilai $R$-Square sebesar 0,263 yang berarti PKM mempengaruhi variabel KPC sebesar 26,3\% sedangkan sisanya sebesar $73,7 \%$ dipengaruhi oleh variabel lainnya. Nilai $R$-Square pada variabel RSK sebesar 0,496 yang menandakan variabel KPC mempengaruhi variabel RSK sebesar 49,6\% sedangkan sisanya sebesar 50,4\% dipengaruhi oleh variabel lainnya. Variabel SKP memiliki $R$-Square sebesar 0,936 yang berarti variabel PKG, PKM, RSK dan SHC, mempengaruhi variabel SKP sebesar 93,6\% sedangkan sisanya sebesar $6,4 \%$ dipengaruhi oleh variabel lainnya. $R$-Square pada Variabel NMG sebesar 0,482 yang berari bahwa variabel NS dan SKP mempengaruhi variabel NMG sebesar $48,2 \%$ dan sisanya sebesar $51,8 \%$ dipengaruhi oleh variabel lain.

\section{Pengaruh Norma Subjektif (NS) Terhadap Persepsi Kegunaan (PKG)}

Hasil hipotesis pertama (H1) diterima, artinya norma subjektif berpengaruh terhadap persepsi kegunaan fintech syariah. Pada Tabel 2 H1 memiliki nilai path coefficients sebesar 0,194, sehingga norma subjektif berpengaruh positif dan signifikan terhadap persepsi kegunaan fintech syariah. Hal ini dapat dikatakan bahwa semakin tinggi norma subjektif yang dimiliki seseorang maka persepsi dirinya terkait kegunaan fintech syariah juga semakin tinggi. Hasil penelitian ini mendukung penelitian sebelumnya yang telah dilakukan oleh Amalia (2018); Niswah, Mutmainah, and Legowati (2019) bahwa norma subjektif berpengaruh terhadap persepsi kegunaan atau manfaat. Semakin tinggi dorongan dari orang-orang terdekat yang dalam hal ini adalah keluarga, teman dekat, lingkungan masyarakat maka akan membentuk persepsi bagi penggunanya akan manfaat dari fintech syariah.

\section{Pengaruh Norma Subjektif (NS) Terhadap Niat Menggunakan (NMG)}

Hasil hipotesis kedua (H2) diterima, artinya norma subjektif berpengaruh positif terhadap niat menggunakan fintech syariah. Pada Tabel $2 \mathrm{H} 2$ memiliki nilai path coefficients sebesar -0,166, sehingga norma subjektif berpengaruh negatif terhadap niat menggunakan fintech syariah. Hal ini dapat dikatakan bahwa semakin tinggi norma subjektif yang dimiliki seseorang maka semakin rendah niat atau minat untuk menggunakan fintech syariah. Hasil ini bertolak belakang dengan penelitian yang dilakukan oleh Monica and Tama (2017); Amalia (2018); Safitri, Musityo, and Wardhani (2019). Perbedaan hasil pada penelitian ini dengan penelitian sebelumnya didukung dengan adanya profil responden yang sebagian besar belum menggunakan fintech syariah. Keadaan ini menunjukkan bahwa rendahnya minat menggunakan fintech syariah dipengaruhi oleh faktor-faktor sosial yaitu lingkungan, orang-orang terdekat atau tokoh-tokoh penting yang mengajak untuk menggunakan fintech syariah sebagai layanan keuangannya.

\section{Pengaruh Persepsi Kegunaan (PKG) Terhadap Sikap (SKP)}

Hasil hipotesis ketiga (H3) ditolak, artinya persepsi kegunaan tidak berpengaruh terhadap sikap dalam menggunakan fintech syariah. Hal ini menandakan bahwa semakin tinggi atau rendah persepsi kegunaan fintech syariah maka tidak ada pengaruh terhadap sikap seseorang untuk menggunakan teknologi tersebut. Hasil ini mendukung penelitian yang telah dilakukan oleh Niswah, Mutmainah, and Legowati (2019) bahwa persepsi kegunaan tidak berpengaruh 
terhadap sikap untuk menggunakan platform fintech sebagai tempat untuk melakukan donasi. Hal ini disebabkan karena fintech merupakan salah satu teknologi yang masih baru dan terus dalam tahap perkembangan, sehingga belum bisa diaplikasikan secara totalitas pada aktivitas sehari-hari. Kondisi ini juga didukung dengan pola pikir masyarakat yang masih dalam tahap tradisional, sehingga butuh waktu untuk merubahnya ke tahap modern.

\section{Pengaruh Persepsi Kemudahan Menggunakan (PKM) Terhadap Persepsi Kegunaan (PKG)}

Hasil hipotesis keempat (H4) diterima, artinya persepsi kemudahan menggunakan berpengaruh terhadap persepsi kegunaan fintech syariah. Pada Tabel 2 H4 memiliki nilai path coefficients sebesar 0,656, sehingga persepsi kemudahan menggunakan berpengaruh positif dan signifikan terhadap persepsi kegunaan fintech syariah. Hasil ini menunjukkan bahwa semakin tinggi persepsi kemudahan menggunakan maka semakin tinggi pula persepsi kegunaan fintech syariah. Hasil penelitian ini mendukung penelitian yang dilakukan oleh Wixom and Todd (2005); Shipps and Phillips (2013); Priyono (2017); Amalia (2018); Sari, Safitri, and Anggraini (2019); bahwa para pengguna merasa dengan hadirnya sebuah teknologi mudah untuk dipelajari dan digunakan sesuai dengan kebutuhan yang diinginkan, sehingga mampu memberikan manfaat untuk menyelesaikan pekerjaan secara lebih cepat.

\section{Pengaruh Persepsi Kemudahan Menggunakan (PKM) Terhadap Kepercayaan (KPC)}

Hasil hipotesis kelima (H5) diterima, artinya persepsi kemudahan menggunakan berpengaruh terhadap kepercayaan menggunakan fintech syariah. Pada Tabel 2 H5 memiliki nilai path coefficients sebesar 0,512, sehingga persepsi kemudahan menggunakan berpengaruh positif dan signifikan terhadap kepercayaan menggunakan fintech syariah. Kepercayaan merupakan keyakinan yang kuat terkait sesuatu yang mampu diandalkan keberadaannya. Dalam penelitian ini masyarakat Yogyakarta berkeyakinan bahwa hadirnya teknologi berupa fintech syariah, mampu melakukan aktivitas keuangan yang dibutuhkan. Melalui persepsi kemudahan menggunakan yang dirasakan oleh pengguna, membuktikan bahwa fintech syariah dipercaya sebagai alat untuk mengelola kebutuhan keuangan yang diperlukan, baik itu kebutuhan dalam bentuk pembayaran, crowdfunding, berdonasi atau yang lainnya. Hasil penelitian ini sejalan dengan penelitian yang dilakukan oleh Gefen, Karahanna, and Straub (2003); Pavlou (2014); Priyono (2017) bahwa ketika pemilik dari perusahaan teknologi mampu mengelola teknologi yang ditawarkan menjadi lebih mudah untuk digunakan dan dioperasikan maka dapat diartikan bahwa perusahaan tersebut telah berkomitmen untuk menjaga hubungan antara dirinya dengan pengguna atau pelanggan. Oleh karena itu akan berpengaruh terhadap keyakinan pengguna bahwa teknologi yang dipilih dapat dipercaya. Sehingga hasil ini menandakan bahwa semakin tinggi persepsi kemudahan menggunakan fintech syariah maka semakin tinggi pula kepercayaan masyarakat untuk menggunakan teknologi tersebut. 


\section{Pengaruh Persepsi Kemudahan Menggunakan (PKM) Terhadap Sikap (SKP)}

Hasil hipotesis keenam (H6) diterima, artinya persepsi kemudahan menggunakan berpengaruh terhadap sikap dalam menggunakan fintech syariah. Pada Tabel 2 H6 memiliki nilai path coefficients sebesar 0,656, sehingga persepsi kemudahan menggunakan berpengaruh positif dan signifikan terhadap sikap dalam menggunakan fintech syariah. Hal ini berarti semakin tinggi persepsi kemudahan dalam menggunakan fintech syariah maka semakin tinggi pula sikap seseorang untuk mengadopsi teknologi tersebut. Sejalan dengan hasil penelitian yang di lakukan oleh Wixom and Todd (2005); Shipps and Phillips (2013); Chuang, Liu, and Kao (2016); Nurul and Ningrat (2018); Sari, Safitri, and Anggraini (2019) bahwa persepsi kemudahan menggunakan mempengaruhi sikap dari penggunanya. Ketika sebuah teknologi mudah untuk digunakan, maka akan mempengaruhi sikap dari pengguna tersebut untuk mengadopsinya baik di masa sekarang mapun yang akan datang. Sari, Safitri, and Anggraini (2019) menjelaskan bahwa kemudahan menggunakan berpengaruh terhadap sikap untuk menggunakan $m$-banking syariah. Di saat pengguna $m$-banking syariah merasa mudah dan mampu mengoperasikan m-banking tersebut secara kesuluruhan, maka pengguna tersebut akan beranggapan bahwa dengan menggunakan m-banking syariah untuk urusan bisnis atau pekerjaan merupakan ide yang menarik. Alasan ini tentu akan sama halnya bagi pengguna fintech syariah yang beranggapan bahwa dengan kemudahan yang ditawarkan oleh fintech syariah, maka secara tidak langsung akan mempermudah kebutuhan dari penggunanya, baik itu dalam hal transaksi keuangan berupa pinjaman, pembayaran, berdonasai atau yang lainnya. Selain itu, hasil penelitian ini juga sejalan dengan pandangan dari model $T A M$ yang menyatakan bahwa sikap seseorang akan keberadaan sebuah teknologi disebabkan oleh kemudahan dalam menggunakan teknologi tersebut sehingga orang tersebut tidak membutuhkan banyak usaha pada saat mengoperasikannya.

\section{Pengaruh Kepercayaan (KPC) Terhadap Risiko (RSK)}

Hasil hipotesis ketujuh (H7) diterima, artinya bahwa kepercayaan berpengaruh terhadap risiko menggunakan fintech syariah. Pada Tabel 2 H7 memiliki nilai path coefficients sebesar 0,704 , sehingga kepercayaan berpengaruh positif dan signifikan terhadap risiko menggunakan fintech syariah. Risiko merupakan suatu akibat akan sebuah kejadian atau perbuatan yang merugikan pelaku atau penggunanya. Penelitian ini kepercayaan berpengaruh positif dan signifikan terhadap risiko menggunakan fintech syariah. Hal ini menunjukkan bahwa pengguna fintech syariah menaruh kepercayaan yang sangat positif terhadap fintech syariah. Kepercayaan yang berasal dari kehebatan atau keandalan dari fintech syariah ini turut berpengaruh terhadap tingkat risiko yang akan dirasakan oleh penggunanya. Meskipun pengguna merasa dengan memilih fintech syariah akan dihadapkan dengan risiko yang besar, akan tetapi dengan adanya kepercayaan tinggi dari penggunanya hal itu tetap mendorong mereka memilih untuk menggunakan fintech syariah. Penelitian ini bertolak belakang dengan penelitian Priyono (2017) yang menyatakan bahwa kepercayaan berpengaruh negatif terhadap persepsi risiko. 


\section{Pengaruh Risiko (RSK) Terhadap Sikap (SKP)}

Hasil hipotesis kedelapan (H8) diterima, artinya risiko berpengaruh terhadap sikap dalam menggunakan fintech syariah. Pada Tabel 2 H8 memiliki nilai path coefficients sebesar 0,165 , sehingga risiko berpengaruh positif dan signifikan terhadap sikap dalam menggunakan fintech syariah. Hal ini menunjukkan bahwa semakin tinggi risiko yang akan dihadapi pengguna fintech syariah maka akan berpengaruh secara positif terhadap sikap dalam menggunakan teknologi tersebut. Melihat dari nilai path coefficient yang positif mendekati nol, ini menunjukkan bahwa risiko tidak berpengaruh negatif terhadap sikap untuk menggunakan fintech syariah, hal ini memiliki kemungkinan bahwa perusahaan fintech syariah mampu meyakinkan penggunanya bahwa risiko yang ada dapat ditekan dan diminimalisir.

\section{Pengaruh Sharia Compliance (SHC) Terhadap Sikap (SKP)}

Hasil hipotesis kesembilan (H9) diterima, artinya sharia compliance berpengaruh terhadap sikap seseorang dalam menggunakan fintech syariah. Pada Tabel 2 H9 memiliki nilai path coefficients sebesar 0,797, sehingga sharia compliance berpengaruh positif dan signifikan terhadap sikap seseorang dalam menggunakan fintech syariah. Hal ini menunjukkan bahwa semakin tinggi sharia compliance yang dimiliki fintech syariah maka semakin tinggi pula sikap seseorang untuk menggunakan teknologi tersebut. Kondisi ini merujuk kepada persepsi pengguna bahwa ketika fintech syariah yang digunakan sudah patuh terhadap prinsip-prinsip syariah.

\section{Pengaruh Sikap (SKP) Terhadap Niat Menggunakan (NMG)}

Hasil hipotesis kesepuluh (H10) diterima, artinya sikap berpengaruh terhadap niat menggunakan fintech syariah. Pada Tabel $2 \mathrm{H} 10$ memiliki nilai path coefficients sebesar 0,716, sehingga sikap berpengaruh postitif dan signifikan terhadap niat menggunakan fintech syariah. Hal ini menunjukan bahwa semakin tinggi sikap seseorang terhadap fintech syariah maka semakin besar niat untuk menggunakan teknologi tersebut. Hasil penelitian ini mendukung beberapa penelitian yang dilakukan oleh Chuang, Liu, and Kao (2016); Aslam, Ham, and Arif (2017); Amalia (2018) yang menyatakan bahwa niat seseorang dalam menggunakan suatu teknologi dipengaruhi oleh sikap mereka terhadap teknologi tersebut. Ketika seorang individu merasakan bahwa kehadiran fintech syariah memberikan dampak baik dan positif, maka niat orang tersebut untuk menggunakan fintech syariah semakin tinggi. Selain itu hasil penelitian ini juga mendukung model TAM yang diajukan oleh Ajzen and Fishbein (1977) yang menyatakan bahwa niat seseorang dalam menggunakan sebuah teknologi didorong oleh sikap mereka terhadap teknlogi tersebut. Hal ini juga menunjukkan bahwa sikap dari responden penelitian ini pada dasarnya mendukung atau menerima fintech syariah sebagai bentuk layanan keuangannya. Adanya sikap positif tersebut akan mendorong masyarakat untuk menggunakan layanan tersebut di masa yang akan datang. 


\section{KESIMPULAN}

Secara umum hipotesis yang diajukan diterima, kecuali hipotesis ketiga ditolak, yang mana persepsi kegunaan tidak berpengaruh terhadap sikap dalam menggunakan fintech syariah. Sedangkan faktor yang memiliki peran paling besar terhadap penerimaan fintech syariah adalah sikap dan sharia compliance. Hal ini mengingat bahwa semakin positif sikap seseorang terhadap sebuah teknlogi maka semakin besar niat untuk mengadopsinya. Disamping itu hadirnya sharia compliance juga memperkuat sikap seseorang untuk mengadopsi fintech syariah sebagai layanan keuangan pribadinya. Karena selain manfaat yang didapatkan, pengguna juga akan merasa setiap transaksi yang dilakukan sudah berdasarkan prinsip syariah.

Hasil penelitian ini dapat menjadi sumber referensi baru bagi para peneliti di masa mendatang yang memilih topik kajian yang sama terkait penerimaan sistem atau teknologi dibidang keuangan. Selain itu, dapat memberikan kontribusi mengenai hal apa saja yang mempengaruhi penerimaan fintech syariah di Indonesia, khususnya pada masyarakat Yogyakarta. Sehingga dapat dijadikan rujukan dan pertimbangan bagi perusahaan-perusahaan fintech syariah untuk dapat mengembangkan layanannya dan meningkatkan kualitas serta fungsi dari fintech syariah yang sudah ada saat ini.

Penelitian ini menggunakan sampel sebanyak 150 orang, yang mana dari sampel tersebut belum semuanya pengguna fintech syariah, sehingga belum bisa mewakili dari pengguna fintech syariah itu sendiri. Oleh sebab itu bagi peneliti selanjutnya agar dapat memperluas sampel serta dapat mengembangkan variabel yang belum digunakan pada penelitian ini, seperti pengetahuan terkait fintech syariah. Karena beberapa responden masih banyak yang belum tahu tentang fintech syariah dan manfaat apa saja yang akan didapat dari menggunakan fintech syariah.

\section{DAFTAR PUSTAKA}

Abdillah, Willy, and Jogiyanto Hartono. 2015. Partial Least Square (PLS) Alternatif Structural Equation Modeling (SEM) dalam Penelitian Bisnis. Yogyakarta: Penerbit Andi, 2015.

Ajzen, Icek, and M. Fishbein. 1977. "Attitude-Behavior Relations: A Theoretical Analysis And Review Of Empirical Research". Psychological Bulletin 84 (5), 888-918. https://psycnet.apa.org/doi/10.1037/0033-2909.84.5.888.

Amalia, Siti Nur Annisa. 2018. "Faktor-Faktor yang Mempengaruhi Minat Individu Terhadap Financial Technology (FinTech) Syariah (Paytren) Sebagai Salah Satu Alat Transaksi Pembayaran (Pendekatan Technology Acceptane Model (TAM) dan Theory of Planned Behavior (TPB)". IQTISHADUNA 9 (1), 57-73. https://journal.uinmataram.ac.id/index.php/iqtishaduna/article/view/687.

Arner, Douglas W., Janos Barberist, Ross P. Buckley. 2015. "The Evolution of FinTech: A New Post-Crisis Paradigm?". University of Hong Kong Faculty of Law Research Paper No. 2015/047 UNSW Law Research Paper No. 2016-62, 1-45. https://doi.org/10.2139/SSRN.2676553. 
Aslam, Wajeeha, Marija Ham, and Imtiaz Arif. 2017. "Consumer Behavioral Intentions towards Mobile Payment Services: An Empirical Analysis in Pakistan”. $\quad$ Market-Tržište $29 \quad$ (2), 161-176. https://doi.org/10.22598/mt/2017.29.2.161.

Chin, Wynne W. 1998. Modern Methods For Business Research: The Partial Least Square Approach to Structural Equation Modeling. New Jersey: Lawrence Erlbaum Associates Inc. http://www.researchgate.net/publication/232569511.

Chuang, Li-Min, Chun-Chu Liu, and Hsiao-Kuang Kao. 2016. "The adoption of fintech service: TAM perspective". International Journal of Management and Administrative Sciences (IJMAS) 3 (7), 1-15. https://www.ijmas.org/37/IJMAS-3601-2016.pdf.

Davis, Fred D. 1989. "Perceived Usefulness, Perceived Ease of Use, and User Acceptance of Information Technology". MIS Quarterly 13 (3), 319-340. https://doi.org/10.2307/249008.

Davis, Fred D., Richard P. Bagozzi, Paul R. Warshaw. 1989. "User Acceptance of Computer Technology: A Comparison of Two Theoretical Models". $\begin{array}{llll}\text { Management } & \text { Science } & 35 & \text { (8), }\end{array}$ https://doi.org/10.1287/mnsc.35.8.982.

Fishbein, M., and Icek Ajzen. 1975. Belief, Attitude, Intention And Behaviour: An Introduction To Theory And Research. MA: Addison-Wesley.

Fornell, Claes, and David F. Larcker. 1981. "Evaluating Structural Equation Models with Unobservable and Measurement Error". Journal of Marketing Research 18 (1), 39-50. https://doi.org/10.1177/002224378101800104.

Gefen, David, Elena Karahanna, and Detmar W. Straub. 2003. "Trust and TAM in Online Shopping An Integrated Model”. MIS Qarterly 27 (1), 51-90. https://doi.org/10.2307/30036519.

Ghozali, Imam. 2006. Structural Equation Modelling Metode Alternatif dengan PLS, Edisi Kedua. Semarang: BP Undip.

Janusi, Rahman El. 2012. "Implementasi Syariah Governance Serta Implikasinya Terhadap Reputasi dan Kepercayaan Bank Syariah". Al-Tahrir: Jurnal $\begin{array}{llll}\text { Pemikiran } & \text { Islam } & 12 & \text { (1), }\end{array}$ https://jurnal.iainponorogo.ac.id/index.php/tahrir/article/view/48.

Kim, Dan J., Donald L. Ferrin, and H. Raghav Rao. 2008. "A Trust-Based Consumer Decision-Making Model In Electronic Commerce: The Role Of Trust, Perceived Risk And Their Antecedents". Decision Support Systems 44 (2), 544-564. https://doi.org/10.1016/j.dss.2007.07.001.

Monica, Nina, and Annafi Indra Tama. 2017. "Pengaruh Persepsi Manfaat, Persepsi Kemudahan, Persepsi Kenyamanan, Norma Subjektif, dan Kepercayaan Terhadap Minat Menggunakan Electronic Commerce". JRAK: Jurnal Riset Akuntansi \& Komputerisasi Akuntansi, 8 (1), 27-41. http://jurnal.unismabekasi.ac.id/index.php/jrak/article/view/803.

Nasution, Dewi Sartika. 2017. "Urgensi Fintech dalam Kurikulum Perguruan $\begin{array}{lllll}\text { Tinggi”. } & \text { IQTISHADUNA } & 8 & \text { (2), } & \text { 116-129. }\end{array}$ https://journal.uinmataram.ac.id/index.php/iqtishaduna/article/view/389.

Niswah, Farokhah Muzayinatun, Lu'liyatul Mutmainah, and Diah Ayu Legowati. 2019. "Muslim Millennial's Intention of Donating for Charity Using 
Fintech Platform". Journal of Islamic Monetary Economics and Finance 5 (3), 623-644. https://doi.org/10.21098/jimf.v5i3.1080.

Nizar, Muhammad Afdi. 2017. "Teknologi Keuangan (Fintech): Konsep dan Implementasinya di Indonesia". Warta Fiskal (5), 5-13. https://www.researchgate.net/publication/323629323_Teknologi_Keuanga n_Fintech_Konsep_dan_Implementasinya_di_Indonesia.

Nurul, Maulia, and R. Gratiyana Ningrat. 2018. "Adopsi Teknologi Muslim, Sikap dan Intensi Pembelian Produk Investasi Islam Menggunakan Financial Technology". Journal of Economics and Business Aseanomics (JEBA) 3 (2), 155-175. https://doi.org/10.33476/jeba.v3i2.958.

OJK. 2019. Statistik Fintech Lending Periode Desember 2019. Diakses dari https://www.ojk.go.id/id/kanal/iknb/data-danstatistik/fintech/Pages/Statistik-Fintech-Lending-Periode-Desember2019.aspx.

Pavlou, Paul A. 2014. "Consumer Acceptance of Electronic Commerce: Integrating Trust and Risk with the Technology Acceptance Model". International Journal of Electronic Commerce 7 (3), 101-134. https://doi.org/10.1080/10864415.2003.11044275.

Priyono, Anjar. 2017. "Analisis Pengaruh Trust dan Risk Dalam Penerimaan Teknologi Dompet Elektronik Go-Pay”. Jurnal Siasat Bisnis 21(1), 88106. https://doi.org/10.20885/jsb.vol21.iss1.art6.

Safitri, Ernita Oktaviana, Yusi Tyroni Musityo, and Niken Hendrakusuma Wardhani. 2019. "Analisis Perilaku Penggunaan Mobile Payment Aplikasi OVO Menggunakan Technology Acceptance Model (TAM) Termodifikasi". Jurnal Pengembangan Teknologi Informasi dan Ilmu Komputer 3 (8), 8184-8189. https://j-ptiik.ub.ac.id/index.php/jptiik/article/view/6120.

Sari, Firdausa Kumala, Novita Safitri, and Wahyu Anggraini. 2019. "Trust on Sharia M-Banking: Evidance on Milenials Generations". JIES: Journal of Islamic Scholar, 29-41.

Shipps, Belinda, and Brandis Phillips. 2013. "Social Networks, Interactivity and Satisfaction: Assessing Socio-Technical Behavioral Factors as an Extension to Technology Acceptance". Journal of Theoritical and Applied Electronic Commerce Research 8 (1), 35-52. https://doi.org/10.4067/S0718-18762013000100004.

Siregar, Khairani Ratnasari. 2011. "Kajian Mengenai Penerimaan Teknologi dan Informasi Menggunakan Technology Accaptance Model (TAM)". Rekayasa 4 (1), 27-32. https://journal.trunojoyo.ac.id/rekayasa/article/view/2322.

Siri, Moh., Fitriyani Fitriyani, and Asti Herliana. 2017. "Analisis Sikap Pengguna Paytren Menggunakan Technology Acceptance Model”. Jurnal Informatika 44 (1), 66-75. https://ejournal.bsi.ac.id/ejurnal/index.php/ji/article/view/1613.

Wixom, Barbara H., and Peter A. Todd. 2005. "A Theorical Integration of User Satisfaction and Technology Acceptance". Information System Research 16 (1), 85-102. https://www.doi.org/10.1287/isre.1050.0042.

World Bank Group. (2016). The Little Data Book 2016. World Bank Publications. https://data.worldbank.org/products/data-books/little-data-book. 